\title{
PRODUCTIVITY COMPARISON
}

\author{
V. NYITRAI \\ (Received: 22 March 2001; revision received: 23 May 2001; \\ accepted: 3 September 2001)
}

\begin{abstract}
The present paper deals with an international comparison of labour productivity, as well as with total factor productivity comparison made by different international organisations, e.g. the OECD. These kinds of comparisons do not contain data regarding transition countries in the 20th century. Long-term comparisons yield an analysis of the several factors influencing productivity trends, among which human factors have an increasing role. The second part of the paper gives several kinds of information about the tendencies of the Hungarian labour productivity on a national and branch level. The most important development can be seen in the engineering industry. A short part of the paper illustrates the development of total factor productivity in Hungary between 1992 and 1997.
\end{abstract}

Keywords: labour productivity, total factor productivity, international comparison, factors influencing the level of productivity, structural changes in Hungary.

JEL classification index: D24, O57.

\section{THEORETICAL APPROACH}

The theory of measurement of productivity growth has a long tradition worldwide. Productivity growth as a proxy of national growth accounting was mentioned already by Solow (1957). Academic literature has dealt with labour productivity as well as with total factor productivity for several decades not only in the most developed countries but also in Hungary (especially in the 1970s and 1980s).

The theoretical side of this problem has received considerable attention and has been debated over the last decade of the 20th century when the "new economy" put this matter in a brand new light. I would like to mention only some of the recent studies among the wide range of literature on this topic.

Correspondence: V. Nyitrai, Central Statistical Office of Hungary, H-1024 Budapest, Keleti Károly u. 5-7, Hungary. E-mail: ferencne.nyitrai@ksh.gov.hu 
Among others in Canada and in the United States Daly and Rao (1985), Denny et al. (1992), Fuess and Van den Berg (1992), and Bernstein (1998) studied the role of total factor productivity (TFP) in cross-country comparisons, underlining the growing importance of capital productivity. Their studies proposed several new kinds of explanations. Usually the well-known Cobb-Douglas production function was used for sector (or branch) and country analyses.

Jorgenson and Yip calculated in 1999 some constant-quality indices for capital and labour inputs. These indices were based on a disaggregation of the capital stock and labour force and were weighted by rental prices and wages, respectively. The basic concept of this measurement was that the above-mentioned weights are suitable to capture the impact of the differential effects of investment in tangible and human capital. The quality of capital was calculated - in a new work of Cerisola and Chan-Lau (2000) - as the ratio of capital input to the capital stock, while the quality of labour was calculated as the ratio of the labour input index to total hours worked. The Cerisola-Chan-Lau study appeared as a working paper of the IMF and aimed to disaggregate the productivity of different branches into "investment-specific" and "technically neutral" productivity. Decomposing productivity growth into these two sources means that the investment-specific productivity is based on technical changes associated with improvements in the quality of capital stocks. The so-called neutral technical productivity change is mostly associated with the organisation of productive activities.

The result of the study had shown what was expected, namely that the investment-specific technical change could give the opportunity of narrowing the productivity gap between two differently developed countries. From the point of view of a transition country this result indicates much more: aiming to achieve or to approach the productivity level of the more developed EU countries in the near future could be performed only in some specific branches where a robust investment has to be realised. Continuous structural reforms at a macroeconomic level will be required as well. Without incorporating new technologies in some leading branches associated with a higher level of $\mathrm{R} \& \mathrm{D}$ costs, it is quite impossible to narrow the present gap between Hungary and the majority of EU countries.

Another study series dealing with the measurement and the factors influencing the productivity level (labour and total factor productivity as well) has been published by Nordhaus (2001). The three papers of the series examined the welfare-theoretic basis for measuring productivity growth in detail, producing a new technique for decomposing this into three factors, namely indicating the pure productivity effect, separately the effect of changing shares and the effect of different productivity levels. These three components can help in building a welfare-oriented measure of productivity growth based on a relatively simply model. Nordhaus presents the theoretical results on practical data as well, using a newly 
constructed set of "new-economy" accounts. The author defined the new-economy as the aggregate of machinery, electric equipment, telephone and telegraph as well as software. This is undoubtedly a simplification and not the only one; the author also constructed a "well-measured output", which includes outputs of these sectors for which measurement is relatively easily soluble.

Nordhaus' study series is undoubtedly impressive but could also be debated. First of all he concentrates mostly on information technology (IT) and high-tech industries but the economy includes several more traditional activities and branches and their level of productivity cannot be left out of consideration. Moreover, the branches without "well-measured output" are playing a growing role in the economy as a whole and measuring their productivity growth as theoretically as practically is not simple. Finding some common methods in different countries for this purpose can presumably be the task of the future. Another problem is that the relative productivity level of a certain economy is closely connected with living standards, therefore it could be dangerous to study only a part of the existing branches and not the economy as a whole. Keeping in mind the last theoretical results of the examination of this topic, let us have a look at the practical side.

It is well known that for several decades, the most efficient way of comparing the extent of economic development and standards reached in various countries has been the international productivity comparison. The appearance of the new economy and globalisation has not made this subject irrelevant. On the contrary, it is now more relevant than ever before. What needs to be examined in the course of productivity comparison?

1) Dynamism of labour productivity (GDP, GNI or output per person and/or per completed hour) per country: this is the simplest and most common method of comparison. All the data are available for making such comparisons, broken down according to branches or in certain cases according to activity groups, and on the basis of more or less the same methodology. These data are reliable and exact in the processing industry, and agriculture and trade, while in the field of services they are based on estimation to a significant extent (and the estimation is not based on completely identical methods in the individual countries). ${ }^{1}$ There is also a large amount of data regarding standard influencing factors.

2) Total factor productivity: the international comparison of the joint average productivity of labour and capital is a complex method with remarkable traditions. Excellent examples can be found in international practice, but infrequently.

There is an other aspect of the measurement of the productivity level, namely that which kind of production indicator should be used: GDP, GNI, net or gross output, but I shall not deal with this problem in this paper. 
3) Productivity level comparison: is the most complex - and in my opinion the most valuable - method, it can also serve as a basis for later comparisons of dynamism. Such comparisons can be made with respect to a single year or several years. Even though they require a significant amount of work from statisticians and other specialists of the participating countries, nowadays they are essential for realistic situation surveys.

The problem with the first two basic methods is that the basis determines everything. To modelise it with a Hungarian example: a completely different trend line is obtained if the year 1989, 1990 or 1992 is taken as a basis. If the three different trends are compared to the productivity development of any of the developed countries (such as Austria, Finland or even Ireland), we get a completely different picture in each case, as the trend is significantly influenced by the economic discontinuity that took place around the change of the political system. Consequently, comparisons of dynamism are necessary but inadequate in the realistic analysis of the change in the Hungarian situation. The same problem arises when examining the productivity of other transition countries as compared to developed countries, and even in the course of comparing transition countries to each other.

The method to be used for international productivity comparison has to take into consideration that the productivity level of a country is one of the major components of the competitiveness of the country. This is the case in the most developed as well as in the transition countries. Analysing the relative level of productivity of the Hungarian economy has therefore an outstanding significance.

\section{THE LATEST PRODUCTIVITY ANALYSES OF THE OECD}

All international organisations of the OECD have for many years dealt with labour productivity comparisons and the analysis of factors with the highest influence. In order to show how relevant and important this significant international organisation finds this subject during this period of globalisation, I shall mention three examples all of which are so-called working papers of the OECD: one of them was published in 1999 and the other two in 2000. Obviously these studies did not primarily and exclusively deal with productivity development, but also analysed the correlation.

The first one was published by Ahn (1999). The primary aim of the paper was to examine the extent to which the use of new technologies ensures productivity development at maximum efficiency in the long run. Despite the fact that in the first phase of using new technologies productivity decreases temporarily, in the long run the revival of technology undoubtedly results in the improvement of productivity. The expression "productivity puzzles" used in the title is taken from in- 
formation technology literature and was first coined in connection with the development of the Asian economy. As it is known, in the 1980s the multinational companies operating in the United States made very large-scale investments in the field of information technology, and in this period only very slight production improvement could be observed at these companies. At the same time total factor productivity in the recently industrialised countries of Asia developed at a medium rate, although the investments made in modern technologies were also rather impressive there. Ahn's study illuminates the background to these phenomena and processes. Behind the correlation, which is difficult to explain, the researcher - using a mathematical model - initially discovered that the costs of learning of the new technology were an influencing factor. Furthermore, the industrialisation of a less developed economy and its provision with new information technology (as in the example of Asian countries) requires new methods in production management, which also involves significant costs.

The result that the manufacturing industry of the most developed countries (such as Japan and the United States) broken down into 18 branches shows a generally negative correlation between the capital development rate and total productivity development. In other words, productivity development slows down when capital investment development is accelerated. It is obvious here that the time factor or "time-to-build" as the OECD refers to it, also plays a role, which, in simpler words, means that the efficient realisation of an investment requires a certain period of time, and in this period productivity does not increase rapidly. However, when this period expires a more rapid productivity development can be observed in the case of each country examined.

The second OECD publication, which covers a significantly wider scope of the subject, examines the economic growth in the OECD countries, the factors influencing it and, beside output, the productivity development (Scarpetta et al., 2000). Long-term comparison relating to the period between 1970-1998 is highly significant because comparable data are available in connection with a decisive majority of the countries with respect to these periods (the periods between 1970-80, 1980-90 and 1990-98 are examined separately, and within the latter period between 1995-1998 is also analysed by country). Obviously, Germany is an exception as the unification was a disturbing factor in its comparability, and the Czech Republic, Hungary and Poland are also exceptions among the OECD countries, because in these three countries the first data were published only in 1991 or 1992.

The third publication (Bassanini et al., 2000) concentrates more on technological development, knowledge-based economic growth, and it also analyses multifactor productivity and its integration into the achievements of economy. Here again the question arises: whether the slower rate of productivity growth can be explained in a period of significant expansion in research and development. 
THE ANALYSES OF THE EUROPEAN ECONOMIC COMMITTEE

Issue 1/2000 of the Economic Survey of Europe does not deal with productivity, but compares the relative standard of development of the different economies on the basis of the ECP 96 (European Comparison Project). Its data relate to GDP per inhabitant, so while they are not productivity data, they can be used for evaluation (Table 1).

Table 1

Real GDP per capita, 1960-1998

(European Union $=100 \%)$

\begin{tabular}{|c|c|c|c|c|}
\hline Countries & 1960 & 1973 & 1990 & 1998 \\
\hline France & 106 & 111 & 108 & 110 \\
\hline Germany $^{\mathrm{a}}$ & 123 & 115 & 114 & 115 \\
\hline Italy & 88 & 94 & 100 & 102 \\
\hline United Kingdom & 123 & 104 & 98 & 104 \\
\hline Austria & 95 & 99 & 104 & 109 \\
\hline Belgium & 99 & 105 & 104 & 110 \\
\hline Denmark & 120 & 115 & 106 & 119 \\
\hline Finland & 88 & 95 & 100 & 102 \\
\hline Greece & 43 & 63 & 57 & 59 \\
\hline Iceland & 97 & 97 & 107 & 110 \\
\hline Ireland & 61 & 59 & 71 & 110 \\
\hline Luxembourg & 151 & 135 & 147 & 182 \\
\hline Netherlands & 113 & 108 & 99 & 108 \\
\hline Norway & 101 & 95 & 109 & 130 \\
\hline Portugal & 39 & 55 & 60 & 67 \\
\hline Spain & 57 & 75 & 72 & 79 \\
\hline Sweden & 123 & 115 & 106 & 103 \\
\hline Switzerland & 180 & 163 & 131 & 118 \\
\hline Turkey & 33 & 29 & 29 & 33 \\
\hline Canada & 129 & 121 & 114 & 113 \\
\hline United States & 168 & 150 & 140 & 149 \\
\hline Japan & 56 & 97 & 110 & 112 \\
\hline Western Europe & 96 & 94 & 91 & 91 \\
\hline European Union & 100 & 100 & 100 & 100 \\
\hline
\end{tabular}

Source: Economic Survey of Europe 2000, No 1. New York and Geneva: UN, 2000, p. 166.

a 1950-1990: West Germany.

Table 1 relates to Western Europe and to other highly significant economies outside Europe. It clearly shows that in the long run, over this 38 -year period, the EU countries that were initially less developed (Ireland, Spain, Portugal) were catching up with the leading countries, and that some which had been the leaders regarding their development (such as Germany, the United Kingdom, Sweden and Switzerland) were falling behind. 
However, from the perspective of Hungary, the comparison relating to the relative standard of the transition countries is more interesting (also based on the survey mentioned above).

\section{Table 2}

Per capita GDP of some of the transition economies relative to the European Union ${ }^{\mathrm{a}}$

(Per capita GDP in the European Union $=100 \%$ )

\begin{tabular}{lccccc}
\hline Countries & 1960 & 1975 & 1989 & 1990 & 1995 \\
\hline Bulgaria & 35.6 & 45.3 & 34.5 & 31.6 & 28.4 \\
Czechoslovakia $^{b}$ & 66.5 & 61.3 & 64.9 & 62.4 & 56.9 \\
Hungary & 48.6 & 50.9 & 56.7 & 53.7 & 47.9 \\
Poland & 44.0 & 46.9 & 38.0 & 31.3 & 36.0 \\
Romania & 24.9 & 31.1 & 39.2 & 36.1 & 32.8 \\
\hline
\end{tabular}

a Estimates made by the UN/ECE secretariat for 1960 and 1975, ECP dates for 1989, 1990 and 1995.

${ }^{\mathrm{b}}$ After 1993 the Czech Republic and Slovakia together.

Source: Economic Survey of Europe 2000, No 1. New York and Geneva: UN, 2000, p. 175.

The data in Table 2 seem to be suitable for comparing the orders of magnitude. Also Table 2 indicates that up until the middle of the 90 s the economies of the examined transition countries had not recovered from the significant changes in their relative standards that took place after the change of the political system. Of the five countries, only the Czech Republic and Slovakia maintained their earlier favourable position in relation to the $\mathrm{EU}$ (although today it would be more realistic to examine the standard of the two countries separately). According to ECE calculations Hungary had reached about half of the GDP per capita standard in the EU, and no tendency-like change could be observed until 1995.

The ECE survey mentioned above also provides information regarding the development of industrial labour productivity in the transition countries (Table 3).

Although Table 3 shows data from only a few countries, it can be seen clearly that the most significant and most balanced increase in industrial labour productivity could be observed in Hungary at the end of the 90s. It was followed by a slight change in the real unit labour costs. Perhaps it is not an overstatement that the relative competitiveness of Hungary became more favourable by way of this change. 
Table 3

Labour productivity and real unit labour costs, 1998-1999

(annual average change, $\%$ )

\begin{tabular}{lrrrr}
\hline & \multicolumn{2}{c}{ Labour productivity $^{\mathrm{a}}$} & \multicolumn{2}{c}{ Real unit labour costs $^{\mathrm{b}}$} \\
\cline { 2 - 5 } Countries & 1998 & 1999 & 1998 & 1999 \\
\hline Bulgaria & -9.0 & -4.8 & 7.8 & 12.5 \\
Czech Republic & 2.2 & -2.0 & 2.7 & 7.9 \\
Hungary & 7.5 & 7.3 & -2.7 & 1.7 \\
Poland & 4.6 & 5.9 & 2.5 & -2.2 \\
Romania & -12.0 & -2.8 & 32.1 & 7.2 \\
Slovakia & 8.2 & -1.8 & -1.8 & 7.0 \\
\hline
\end{tabular}

${ }^{\text {a }}$ Gross industrial output deflated by industrial employment.

${ }^{\mathrm{b}}$ Real product wages deflated by productivity.

Source: Economic Survey of Europe 2000, No 1. New York and Geneva: UN, 2000, p. 97.

\section{A few European examples of productivity analysis}

Using the studies of international organisations several developed countries make an effort to determine their place in the world from the aspect of labour productivity development. Here I refer to the remark I made in the introductory part of the present study, that we are talking about the comparison of trends and not the comparison of concrete standards. Generally these trends cover a period of at least 10 years, or even more in certain cases, so on the basis they offer it is possible to follow the changes in the differences in productivity standards and to reveal the causes of these changes.

I shall analyse two examples of the comparisons made by German research institutes of economics: the Institut für Weltwirtschaft an der Universität Kiel, and the Institut der deutschen Wirtschaft Köln. Both research institutes have significant traditions in the field of general economic policy and productivity analyses.

The institute of Kiel, which operates within a university, has issued a large number of working papers over recent years in which they analyse partly the relative competitiveness of European labour productivity, partly the correlation between labour productivity and labour costs and partly the effect of the structural transformation of economy on productivity. ${ }^{2}$

They lean on OECD publications and primarily the data appearing in them, and often use the publication and database of EUROSTAT. It is important to point out that in this case we are talking about a secondary analysis where they partly lean

2 These topics can be found among the studies issued between 1997 and 1999, they are fairly short studies of extremely high quality. 
on the statements of the given sources and partly on their own suppositions. This is the situation when they examine the competitive strength of Europe in relation to the United States in respect to labour productivity or unit labour costs.

In these studies comparability is not always possible because the methods applied, the definition of the data and the method of data collection, are significantly different in the individual countries. However, after counseling caution they draw very daring conclusions, although - as the researchers at Kiel themselves point out - for example the definition of full-time employees or the employment of independent people, that is individual entrepreneurs, appear in the data on the basis of rather different definitions that can significantly influence the standard of productivity. When productivity standards are compared, in the vast majority of the cases they talk about value added per hour or GDP or GNI per hour, so they do not always take productivity per capita as a basis of comparison - as it is stated in nearly all material from Hungary - but rather productivity per hour.

Another important study deals with $R \& D$, the development of processing industry and, within this, productivity (Lektoranta, 1998). This publication does not contain international comparisons, although there are references to it in the material. It is especially interesting because it was written within the scope of the statistical office, and it is based on an entrepreneurial level analysis, examining the correlation between R\&D and productivity for the years 1985, 1987, 1989 and 1991. It then analyses panels created from these years, relating to the periods between 1985-89, 1987-90, 1990-93 and 1991-94, making a distinction between them according to whether the enterprises had any R\&D activities or not. The interesting thing is that the productivity trend is examined over a period of ten years and there are hardly any differences between the two types of company groups.

It seems exemplary that a national statistical office - on the basis of individual entrepreneurial data, across a period of ten years broken down into several periods - tries to examine what effects can be observed between the development of R\&D and labour productivity, and it goes further even comparing the extent of profitability in the case of companies dealing with $\mathrm{R} \& \mathrm{D}$ to differing extents.

\section{THE DEVELOPMENT OF LABOUR PRODUCTIVITY IN HUNGARY AFTER 1990}

It is generally known that for several decades the level of labour productivity of the Hungarian economy in international comparison was extremely low, and not only compared to countries which were much more developed than Hungary, but - on the basis of a detailed bilateral comparison - also within the same region in the 1970s it was lower than in Czechoslovakia. The fact that Hungary was behind 
in this field showed that the efficiency of the Hungarian economy was much lower than that of the other similar countries, even compared to its general level of economic development. This was apparent through productivity comparisons made regularly after the mid-60s, in agriculture and in certain cases in other fields of economy.

From the changes that took place between 1989-2000, the economy produced the most significant improvements in the standard of labour productivity. This is particularly important because in the first few years, until 1991, and in certain branches for an even longer period, the collapse of a large number of business organisations and the changes occurring in certain business organisations resulted in a further reduction of productivity. In certain cases the dismissal of employees in the deteriorating activities came too late and also reduced the level of productivity. The dynamic development experienced over the 90 s started at various times and to differing extents in the individual branches.

The changing of the standard of labour productivity after 1990 is shown in Table 4.

Table 4 illustrates that there was a reduction and stagnation of productivity in 1991 and 1992, which was gradually followed by remarkable productivity growth, although at differing rates from year to year.

In the field of industry the most significant development took place in line with the implementation of privatisation and the arrival of foreign enterprises in Hungary around the mid-90s.

In addition to industry, the fields of transport, post and telecommunications, productivity also grew significantly especially after the mid-90s, while a heterogeneous branch group of other services, to a lesser extent, fluctuated from year to year. In the construction industry the standard of labour productivity changed differently from year to year. This was due to the type of construction work that dominated any given year, to the changes in the prosperity of the industry and finally, how much productivity was influenced by undeclared "black" work, which became almost ubiquitous in the small enterprise construction industry although with differing amounts from year to year.

All these changes that took place from year to year are shown in Table 5, where the extent of changes in productivity can be seen in the individual years compared with the previous year.

The yearly changes clearly show the effect of the following factors:

- In this period the branch composition of the Hungarian national economy went through a significant change that had a great influence on the yearly change of the GDP per capita measured at the level of national economy. 
Table 4

GDP per employee, annual change $(1990=100.0 \%)$

\begin{tabular}{|c|c|c|c|c|c|c|c|}
\hline \multirow[b]{2}{*}{ Year } & \multirow[b]{2}{*}{$\begin{array}{c}\text { Total } \\
\text { productivity }\end{array}$} & \multicolumn{5}{|c|}{ per branch } & \multirow[b]{2}{*}{$\begin{array}{c}\text { other } \\
\text { services }\end{array}$} \\
\hline & & agriculture & industry & $\begin{array}{l}\text { building } \\
\text { industry }\end{array}$ & $\begin{array}{l}\text { trade, repair, } \\
\text { accommodation } \\
\text { services }\end{array}$ & $\begin{array}{l}\text { transport, post, } \\
\text { telecommunications }\end{array}$ & \\
\hline 1991 & 94.0 & 110.9 & 89.1 & 93.4 & 89.5 & 93.3 & 99.2 \\
\hline 1992 & 100.6 & 127.3 & 93.2 & 108.3 & 74.9 & 98.5 & 105.1 \\
\hline 1993 & 106.7 & 154.5 & 107.4 & 107.2 & 74.1 & 96.0 & 108.3 \\
\hline 1994 & 111.9 & 164.1 & 119.1 & 115.6 & 71.5 & 104.0 & 114.0 \\
\hline 1995 & 115.8 & 187.0 & 134.7 & 107.2 & 69.4 & 115.1 & 107.4 \\
\hline 1996 & 118.4 & 190.1 & 140.6 & 97.2 & 66.4 & 116.4 & 116.2 \\
\hline 1997 & 123.8 & 189.1 & 153.8 & 106.0 & 70.3 & 126.3 & 118.9 \\
\hline 1998 & 127.9 & 194.8 & 167.6 & 121.3 & 73.7 & 142.3 & 122.1 \\
\hline 1999 & 129.6 & 205.7 & 180.2 & 113.5 & 70.1 & 146.9 & 121.3 \\
\hline
\end{tabular}

Source: Hungarian Statistics Yearbook, 1999. Budapest: KSH, 2000.

Table 5

GDP per employee (previous year $=100.0 \%$ )

\begin{tabular}{|c|c|c|c|c|c|c|c|}
\hline \multirow[b]{2}{*}{ Year } & \multirow[b]{2}{*}{$\begin{array}{l}\text { Total } \\
\text { productivity }\end{array}$} & \multicolumn{5}{|c|}{ per branch } & \multirow[b]{2}{*}{$\begin{array}{l}\text { other } \\
\text { services }\end{array}$} \\
\hline & & agriculture & industry & $\begin{array}{l}\text { building } \\
\text { industry }\end{array}$ & $\begin{array}{l}\text { trade, repair, } \\
\text { accommodation } \\
\text { services }\end{array}$ & $\begin{array}{l}\text { transport, post, } \\
\text { telecommunications }\end{array}$ & \\
\hline 1991 & 94.0 & 110.9 & 89.1 & 93.4 & 89.5 & 93.3 & 99.2 \\
\hline 1992 & 107.0 & 138.5 & 104.6 & 115.9 & 83.8 & 105.6 & 106.1 \\
\hline 1993 & 106.1 & 121.3 & 115.2 & 99.0 & 98.9 & 97.4 & 103.0 \\
\hline 1994 & 105.0 & 106.2 & 111.0 & 107.8 & 96.4 & 108.4 & 105.3 \\
\hline 1995 & 103.5 & 114.0 & 113.1 & 92.7 & 97.1 & 110.6 & 94.3 \\
\hline 1996 & 102.1 & 101.7 & 104.4 & 90.7 & 95.8 & 101.1 & 108.3 \\
\hline 1997 & 104.6 & 99.5 & 109.4 & 108.9 & 105.8 & 108.5 & 102.4 \\
\hline 1998 & 103.4 & 103.0 & 109.0 & 114.4 & 104.8 & 112.7 & 102.7 \\
\hline 1999 & 101.3 & 105.6 & 107.5 & 93.6 & 95.1 & 103.2 & 99.3 \\
\hline
\end{tabular}


- In the years examined, large-scale privatisation took place in the country's economy, which was followed by an increase in the role of foreign capital and generally resulted in changes involving higher labour productivity in the country, especially in industry.

- The enterprise structure concerning size also changed, and this is also one of the factors influencing the yearly changes in the standard of productivity. In many cases the productivity standard of small enterprises, the number of which increases very rapidly, is lower in reality than that of the medium-sized and large enterprises. Regarding the widespread use of "black" work, the employment of unregistered employees (especially in agriculture and the construction industry as mentioned above) and the yearly changes of their proportion may also have an influence on changes in the indicators of productivity.

- Unquestionably, changes took place in the quality of work. In the individual branches, especially in the field of trade, accommodation services and catering, the standard of productivity fell, while the quality of work improved. In the 90 s, labour productivity decreased from year to year to a greater or lesser extent, but the data do not show how much this change was followed by an improvement in the quality of the work, which is also an efficiency-improving factor.

As a result of the structural changes that took place in Hungarian national economy, the relative dominance of industry declined after 1990 and by the end of the $90 \mathrm{~s}$ it had more or less approached international proportions. This was a natural consequence of the fact that the volume of services increased at a significantly higher rate in line with economic development, and although their proportion in the GDP production did not achieve the level of the developed countries of the European Union, in this field the changes conformed to those that took place in the countries ahead of Hungary.

Today, industry and the construction industry together produce nearly $48 \%$ of GDP, so they have great significance in the national economy. Partly for this reason, and partly because industry deserves special attention in every country from the aspect of labour productivity, let us examine in more detail the development of production per employee in industry, on the basis of the output value per employee measured at comparable prices (Table 6). 
Table 6

Production per employee in industry ${ }^{\mathrm{a}}$

$(\%)$

\begin{tabular}{|c|c|c|c|c|}
\hline \multirow[b]{2}{*}{ Year } & \multirow{2}{*}{$\begin{array}{l}\text { Total } \\
\text { industry }\end{array}$} & \multicolumn{3}{|c|}{ per branch } \\
\hline & & $\begin{array}{l}\text { machine } \\
\text { industry }\end{array}$ & $\begin{array}{l}\text { chemical } \\
\text { industry }\end{array}$ & $\begin{array}{c}\text { food } \\
\text { industry }\end{array}$ \\
\hline \multicolumn{5}{|c|}{ Previous year $=100.0$} \\
\hline 1991 & 96.5 & 96.0 & 89.5 & 102.0 \\
\hline 1992 & 98.6 & 94.5 & 97.3 & 97.3 \\
\hline 1993 & 116.3 & 126.7 & 114.5 & 101.9 \\
\hline 1994 & 114.8 & 126.6 & 107.3 & 115.8 \\
\hline 1995 & 110.6 & 127.6 & 93.3 & 116.5 \\
\hline 1996 & 101.7 & 118.4 & 98.6 & 102.7 \\
\hline 1997 & 109.2 & 147.9 & 105.9 & 96.0 \\
\hline 1998 & 112.0 & 129.0 & 104.8 & 99.5 \\
\hline 1999 & 109.9 & 117.9 & 94.6 & 105.8 \\
\hline 2000 & 116.7 & 139.4 & 107.1 & 108.4 \\
\hline \multicolumn{5}{|c|}{$1990=100.0$} \\
\hline 1991 & 96.5 & 96.0 & 89.5 & 102.0 \\
\hline 1992 & 95.1 & 90.7 & 87.1 & 99.2 \\
\hline 1993 & 110.7 & 114.9 & 99.7 & 101.1 \\
\hline 1994 & 127.0 & 145.5 & 107.0 & 117.1 \\
\hline 1995 & 140.5 & 185.6 & 99.8 & 136.4 \\
\hline 1996 & 142.9 & 219.8 & 98.4 & 140.1 \\
\hline 1997 & 156.0 & 325.0 & 104.2 & 134.5 \\
\hline 1998 & 174.7 & 419.3 & 109.2 & 133.8 \\
\hline 1999 & 192.0 & 494.4 & 103.3 & 141.6 \\
\hline 2000 & 224.1 & 689.1 & 110.6 & 153.5 \\
\hline
\end{tabular}

a On the basis of the output.

Source: Ipar 2000 január-december (Industry January-December 2000). Budapest: KSH, 2001; and partly the author's own calculations.

In both parts of Table 6 the data indicating the changes occurring in the individual years and across the whole period show that within industry the machine industry sector became a propulsive branch where the level of labour productivity increased by 6.9 times between 1990-2000. Productivity increase in the machine industry was especially great in 1997 (47.9\% as compared to the previous year) and in $2000(39.4 \%)$. This dynamic productivity growth is due first of all to modern technology acquired with significant foreign capital and in certain cases to the work of machine industry enterprises performing a new type of activity in Hungarian practice. Modern, very efficiently operating car factories have been established as well as factories producing car parts and partial units. As a result of this in 1997 road vehicle and parts production constituted $33.7 \%$ of the total production of the machine industry. Computer production also increased rapidly, this sub-branch produced $17.2 \%$ of all machine industry production. These two 
branches of the machine industry are also outstanding in respect of their productivity, and together they represent more than half of the output of the machine industry.

In the food industry, which is the other important field of industry, labour productivity increased at a significantly lower rate, and the development of labour productivity in the chemical industry also fluctuated. The food industry, which used to be one of the propulsive branches, significantly increased its productivity in 1994-95, and although foreign enterprises are also dominant in this branch, in the last $2-3$ years they could not produce any perceptible productivity increase. In this area the situation is even more unfavourable in chemical industry where productivity largely stagnated through the 90 s.

Industrial parks play a significant role in the development of industry. In 1997 there were 28 industrial parks in the country, the majority of them in the northwestern Transdanubian region, and fewer in Northeastern Hungary. Nearly 300 enterprises are in operation in the 28 industrial parks, employing nearly 28,000 people. These have invested 140 billion HUF, and with this produced products worth more than 300 billion HUF, 70\% of which has been exported. The establishment of industrial parks was carried out through tenders, placing the less developed eastern areas of the country into the foreground. In 1998, 47 and in 1999 a further 37 bidders were given the title of industrial park, so at the beginning of 2000 there were 112 industrial parks. The most important aim of organising the industrial park system in the country is to help on reducing the regional differences within the country, to give support to the small- and medium-sized enterprises but their indirect effect could be the increasing of the productivity level as well.

The structural changes stated above were largely contributed to the strong export orientation of industry:

- In industrial exports nearly three-quarters of all exports are provided by enterprises that have more than 300 staff. A significant number of these are either partly or completely operating with foreign capital. The share of exports of medium-sized enterprises was nearly $23 \%$, and that of enterprises with less than 50 staff was negligible.

- Industrial exports have been considerably contributed to by the increase in the proportion of passive subcontracting, which no longer means only the passive subcontracting proportion of clothes products (including the shoe industry) - as was the situation in the $70 \mathrm{~s}$ and $80 \mathrm{~s}$ - but also the increase in passive subcontracting in the engineering industry. This is especially noteworthy because from the point of view of labour productivity passive subcontracting - in the output value of which the material value is not taken into consideration - seems to be significantly less value-creating than products 
produced from purchased materials (this, however, is mainly a methodological problem).

- In the field of the most significant exporting branches of industry (computer manufacturing, other communication-technology products, and vehicle production) the level of labour productivity approaches that of the developed European countries and in this a significant role has been played by technology transfer.

- Another factor contributing to the increase of the level of productivity is that as a result of significant investments, new and significantly more modern technology has been brought into the country. The ratio of investments in industry put into operation in the national economy is about $31-33 \%$ (within this that of the processing industry is $22-26 \%$ ). The structural transformation was also aided by those large investments that were put into operation in the chemical industry, in the field of vehicle manufacturing in the engineering industry, in telecommunications and computer manufacturing. The large proportion of these were realised in the scope of foreign-interest enterprises, among which are also those that operate in customs-free areas, and it is certain that this is very favourable for them.

We should also not forget to mention the following factors when evaluating the favourable changes in industry taking place at the level of labour productivity:

- The degree of organisation of work has significantly improved in industry, partly due to the continuous labour supply and partly with respect to the more appropriate utilisation and harmonisation of working time than before.

- The effects of productivity could be felt in the wage levels in different fields of industry, primarily in the already mentioned branches of the engineering industry that have shown exceptional productivity growth.

- The composition of the academic qualifications of employees in industry changed favourably in the 90 s. This is infrequently mentioned but particularly important.

- Similar composition changes have also taken place with respect to employees in certain service fields, especially in property trading, business services and financial services, where the number of active earners has significantly increased, and of these the number of highly qualified young people has increased to the greatest extent. In these service areas the level of labour productivity has also increased significantly greater than the average.

The factors influencing the development of Hungarian labour productivity - as shown above - generally conform to those elements that have been mentioned in 
our international comparison, in other words to technological renewal, which can be realised as investments and technology transfer; to the significant role of the human factor; and, last but not least, to export-oriented development. The role of the time factor cannot really be shown, and this is mainly derived from the fact that the renewal process in the Hungarian economy was nowhere near complete by the end of the millennium, neither structurally speaking, nor in the field of labour productivity and, in connection with this, the specific labour costs. With respect to the latter, it is worth mentioning that from this perspective at the end of the decade Hungary is attractive for foreign capital - although there is stiff competition with the other swiftly transforming countries in the region.

Finally, the country has significant spare capacity in the field of research and development, where in recent years the proportion of investment has decreased, and this was also realised in the slowing down of the utilisation of the research and experimental development by the industry. The number of people employed in company-enterprise R\&D locations was 13017 in 1990, of these 5681 were engaged in scientific research and development. The figure for all those employed in 1997 was 4 682, and within this the number of scientific research workers went down to 2394 . It is noteworthy, however, that the $R \& D$ costs of enterprises between 1991-1997 went up by $210 \%$ at current prices (the industrial price index in 1997 on a basis of $1990=100.0 \%$ was nearly $350 \%$, so investments went down significantly in their volume). The current price value of $R \& D$ investment in 1997 was nearly five times of that in 1991, so in this field there was also a large increase in volume. The $R \& D$ investment of engineering industry and chemical industry enterprises increased at a quicker than average rate, and this is also significant because these two branches employ nearly two-thirds of the researchers employed in the enterprise sector. The productivity development shown in industry and some other, for example, certain telecommunication services fields could be supported a great deal by domestic research and development, even if the result of these is realised not in the short but in the medium or long run.

Overall it can be said that the development of labour productivity in Hungary was one of the significant factors in the transformation of the economy in the past decade, and exceptional improvement in several fields of labour productivity made a significant contribution towards catching up with those countries that are ahead of Hungary in terms of efficiency. The picture, however, is uneven, a general tendency of growth has not yet been realised, and further increases in the competitiveness in this area are justified (Table 7).

Productivity overall developed significantly less favourably than labour productivity in the Hungarian national economy. 
Table 7

The development of overall productivity between 1992-1997 (annual average rate, \%)

\begin{tabular}{|c|c|c|c|}
\hline \multirow{2}{*}{ Branch } & \multicolumn{3}{|c|}{ Productivity } \\
\hline & whole & labour & capital \\
\hline Agriculture & 1.8 & 9.9 & -3.5 \\
\hline Mining & -3.0 & -2.9 & -15.4 \\
\hline Crude oil processing industry & 4.1 & 9.3 & 0.5 \\
\hline Chemical industry & -3.0 & 1.6 & -6.3 \\
\hline Pharmaceutical industry & -5.0 & 2.3 & -9.9 \\
\hline High-tech. engineering industry & 38.0 & 41.4 & 28.1 \\
\hline Intermediate engineering industry & 3.3 & 7.4 & -4.2 \\
\hline Other processing industry & -2.7 & 2.5 & -9.2 \\
\hline Electricity, water, gas supply & 8.9 & 11.1 & 4.5 \\
\hline Remaining processing industry & 2.7 & 7.3 & -5.7 \\
\hline Construction industry & 2.0 & 10.3 & -11.3 \\
\hline Production service & -3.3 & 3.7 & -12.2 \\
\hline Non-production service & -3.6 & 1.9 & -1.0 \\
\hline Primary sectors & -1.2 & 8.9 & -4.6 \\
\hline High-tech. processing industry & 31.7 & 28.0 & 16.0 \\
\hline Intermediate technology & -2.4 & 4.4 & -5.4 \\
\hline Low technology & 8.9 & 7.9 & -4.8 \\
\hline Service & 2.0 & 4.2 & -7.9 \\
\hline National economy total & 0.8 & 6.2 & -6.1 \\
\hline
\end{tabular}

Source: Mikroszkóp 2/1, ECOSTAT (15 January, 1999).

The tendencies from the perspective of capital productivity are the following:

- Fast growth could almost only be seen in the technically more developed branches of the engineering industry, where production increased to an outstanding degree.

- In the other areas of industry, mainly in mining, capital productivity decreased significantly.

- In the construction industry and in the field of services the productivity of capital also went down to a large extent. With respect to some service types the capital built-up in connection with the increasing amount of investments is the result of an effect that is not fully realised, in other words it can be said to be of a temporary character.

In the whole of the national economy in the period between 1992-1997 labour productivity grew only slightly faster than the productivity of capital fell, so the growth in the level of productivity as a whole is insignificant. 


\section{CONCLUSION}

The international productivity comparisons presented and the short illustration of the changes of labour productivity and the factors influencing it in Hungary have shown that the examination of the theoretical as well as of the practical problems of the productivity measurement needs more attention and interest in Hungary as it was experienced in the last decade. Relatively few theoretical studies have concentrated on productivity growth as one of the most important possibilities of sustainable development. Export-oriented development of the most important industrial branches cannot be imagined without an impressive increase of the labour productivity and the TFP. Factors causing the international backlog in this field must be examined not only by using methods prepared by other nation's experts but also by developing special methodological approaches for our (transition) country. For the following generation this could be a desirable task, therefore this paper aims to retire interest in this topic.

\section{REFERENCES}

Ahn, S. (1999): Technology Upgrading with Learning Cost: A Solution for two "Productivity Puzzles”. OECD Working Paper 220, Paris.

Asensio, A. (1991): Économie internationale. Compétitivité et contrainte extérieure: comparaison de dix pays de I'OCDE sur la période 1970-1989. Problèmes Économiques 2, p. 252.

Bassanini, A., Scarpetta, S. and Visco, I. (2000): Knowledge, Technology and Economic Growth Recent Evidence from OECD Countries. OECD Economics Department Working Paper 259, Paris.

Bernstein, J. I. (1998): Total Factor Productivity Growth in the Canadian Life Insurance Industry 1979-1989. Princeton: Princeton University Press.

Blackburn, J. (1990): The Time Factor. National Productivity Review, 9: 4, pp. 395-408.

Britain's Relative Productivity Performance 1950-1996: A Sectoral Analysis (1998): London: NIERS and Economic and Social Research Council.

Buchele, R. and Christiansen, J. (1992): Industrial Relations and Productivity Growth: A Comparative Perspective. International Contributions to Labour Studies, 2, US, pp. 77-97.

Cerisola, M. and Chan-Lau, J. A. (2000): Productivity Trends in Canada. In: Canada-Selected Issues 10. Washington: IMF.

Cörvers, F. (1997): The Impact of Human Capital on Labour Productivity in Manufacturing Sectors of the European Union. Applied Economics, 29, pp. 975-987.

Daly, M. and Rao, P. (1985): Productivity, Scale Economies and Technical Progress. International Journal of Industrial Organization, 3.

Denny, M. et al. (1992): Productivity in Manufacturing Industries, Canada, Japan and the Unites States. Canadian Journal of Economics, August.

Duval, G. (1998): Productivité et valeur ajoutée: des relations complexes. Problèmes Économiques, 2.551, pp. 24-26.

Economic Survey of Europe (2000): New York and Geneva: UN, No. 1. 
Fecher, F. (1992): Croissance de la productivité, rattrapage ou innovation: une analyse des secteurs manufacturiers de I'OCDE. Économie et Prévision, 102-103: 1-2, pp. 117-127.

Fuess, S. M. and Van den Berg, H. (1992): The Impact of Transactions Activities on US. Productivity Growth. Economics Letters, 38.

Hanson, K. and Rose, A. (1997). Factor Productivity and Income Inequality: A General Equilibrum Analysis. Applied Economics, 29, pp. 1061-1071.

Kronemer, A. (1996): Productivity in Industry and Government 1977-94. Monthly Labour Review, November, pp. 43-49.

Lansbury, M., Pain, N. and Smidkova, K. (1996): Foreign Direct Investment in Central Europe since 1990: An Econometric Study. National Institute Economic Review, May, pp. 104-114.

Lektoranta, O. (1999): R\&D, Patenting and Firms' Economic Performance: Study on the Panel Data of Finnish Manufacturing Firms. Helsinki: Statistics Finland.

Magyar Statisztikai Évkönyv (Statistical Yearbook), 1999 (2000): Budapest: KSH.

Neef, A. and Kask, C. (1991): Manufacturing Productivity and Labour Costs in 14 Economies. Monthly Labour Review, December, pp. 24-37.

Nordhaus, W. D. (2001): New Data and Output Concepts for Understanding Productivity Trends. NBER Working Paper 8097, January, p. 35.

Nordhaus, W. D. (2001): Productivity Growth and the New Economy. NBER Working Paper, 8097, January.

Nordhaus, W. D.(2001): Alternative Methods for Measuring Productivity Growth. National Bureau of Economic Research Working Paper 8095, January, p. 19.

Oulton, N. (1997): Total Factor Productivity Growth and the Role of Externalities. National Institute Economic Review, pp. 99-111.

Papaconstantinou, G. (1997): Technology and Industrial Performance. The OECD Observer, 204, pp. 6-10.

Pilat, D. (1996): Competition, Productivity and Efficiency. OECD Economic Studies, 2, 27, pp. $107-146$

Scarpetta, S., Bassanini, A., Pilat, D, and Schreyer, P. (2000): Economic Growth in the OECD Area: Recent Trends at the Aggregate and Sectoral Level. OECD Working Paper 248, Paris.

Sevestre, P. (1990): Qualification de la main-d'oeuvre et productivité du travail. Économie et Statistique, 237-238, pp. 109-118.

Solow, R.M. (1957): Technical Change and the Aggregate Production Function. The Review of Economics and Statistics, 39, pp. 312-320. 
